\title{
Modulation of Hsp60 in response to coral brown band disease
}

\author{
Davide Seveso $^{1,2, *}$, Simone Montano ${ }^{1,2}$, Melissa Amanda Ljubica Reggente ${ }^{1,2}$, \\ Ivan Orlandi ${ }^{1}$, Paolo Galli ${ }^{1,2}$, Marina Vai ${ }^{1}$ \\ ${ }^{1}$ Department of Biotechnologies and Biosciences, University of Milano - Bicocca, Piazza della Scienza 2, Milano 20126, Italy \\ ${ }^{2}$ MaRHE Centre (Marine Research and High Education Centre), Magoodhoo Island, Faafu Atoll, Republic of Maldives
}

\begin{abstract}
Brown band disease (BrB), a virulent coral disease characterized by a dense concentration of ciliates ingesting coral tissue, is responsible for ongoing coral losses on Indo-Pacific reefs. Although several efforts have been made to identify the microbial communities associated with $\mathrm{BrB}$ and study the disease ecology, less attention has been given to the effect of ciliate presence on coral physiology. Levels of the mitochondrial heat shock protein $60-\mathrm{kDa}$ (Hsp60, a biomarker indicative of cellular stress) were analyzed in apparently healthy coral polyps located at different distances along the advancing front of infection in Acropora muricata colonies affected by BrB in a Maldivian reef. Different Hsp60 levels were found in different parts of the same colony. Starting from a basal protein level in the healthy control colonies, a down-regulation of Hsp60 expression was detected near the ciliate band, indicating that the Hsp60 defense activity was probably already compromised due to the rapid progression rate of the BrB ciliate on the diseased branches and/or to the etiology of the disease. Moving away from the band, the Hsp60 levels gradually returned to a state comparable to that found in the control, showing that cellular damage was confined to areas near the infection. In conclusion, we propose the analysis of Hsp60 modulation as a useful tool for examining physiological variations that are not detected at the morphological level in corals subjected to epizootic diseases, while providing new insights into the immune response of corals.
\end{abstract}

KEY WORDS: Coral disease - Ciliates - Brown band disease - Acropora muricata - Hsp60 Maldives $\cdot$ Coral immune system

\section{INTRODUCTION}

Coral diseases have been reported to be increasing in both the occurrence of known diseases and the incidence of newly reported infections, thereby threatening coral reefs worldwide (Sutherland et al. 2004, Cróquer et al. 2006, Weil et al. 2006, 2012, Montano et al. 2013, 2014). In this context, a coral syndrome called the Brown Band (BrB) disease occurring in scleractinians belonging to Acroporidae, Pocilloporidae and Faviidae families on the Great Barrier Reef was described for the first time by Willis et al. (2004). Thereafter, several reports of BrB high- lighted its ongoing spread across the Indo-Pacific, especially affecting corals of the genus Acropora (Raymundo et al. 2009, Lamb \& Willis 2011, Montano et al. 2012).

The macroscopic field sign of the syndrome is the presence of a distinctive brown zone of variable width located between healthy coral tissues and exposed white skeleton. This band is formed by a dense concentration of motile protozoan ciliates that feed on coral tissue and accumulate zooxanthellae (Symbiodinium sp.) intracellularly, resulting in the characteristic brown coloring and in rapid tissue loss (Willis et al. 2004, Ulstrup et al. 2007, Lobban et al. 2011). 
Since different species of ciliates ingest Symbiodinium cells (Bourne et al. 2008, Sweet \& Bythell 2012), the term BrB disease is generally used to describe coral infections characterized by a brown band associated with any ciliate containing Symbiodinium and actively consuming coral tissue (Nicolet et al. 2013, Sweet et al. 2013).

To date, although this disease is well documented and significant efforts have been made in the identification of the associated microbial communities, less attention has been given to the effects of ciliate presence on coral health and physiology, especially considering the high progression rate of the disease (Nicolet et al. 2013, Katz et al. 2014). In this context, the use of molecular biomarkers (e.g. heat shock proteins, Hsps, whose levels can be indicative of cellular stress due to pathogen activity) could clarify some aspects of the typology and severity of damage to coral tissues. It can also provide helpful information about coral stress responses and defense mechanisms before visible signs of disease become apparent. In fact, as ubiquitous molecular chaperones and fundamental cellular protective systems, Hsps are involved in preserving physiological protein homeostasis and maintaining regular cellular functions. They also play a crucial role in protein folding, refolding/unfolding, aggregation, degradation and transport (Sorensen et al. 2003, Mayer 2010, Hartl et al. 2011). In addition, it is well known that the expression of Hsps is upregulated in all organisms, as well as in corals, in order to increase cellular repair and tolerance when environmental variations (both abiotic and biotic) perturb the organism's physiological system (Rossi et al. 2006, Lanneau et al. 2008, Seveso et al. 2012, Ross 2014). Moreover, Hsps are also important factors both in the activation and modulation of the immune response linking cellular stress to immunophysiology (Pockley et al. 2008). In particular, Hsp60 and Hsp70 seem to play a dual role of stress biomarker and immune modulator, in addition to their primary function as molecular chaperones, providing the opportunity to use them as potential therapeutic agents (Pockley et al. 2008, Tsan \& Gao 2009, Quintana \& Cohen 2011). In corals, a recent paper suggests the involvement of the heat stress response gene, $h s p 70$, in the immunological/defense response of Acropora millepora to microbial challenges (Brown et al. 2013). Furthermore, in the coral A. muricata infected by ciliates responsible for the coral disease Skeleton Eroding Band (SEB), an up-regulation of Hsp60 as a defensive mechanism against advancing infection was detected in the coral portions just above the SEB band; this suggests the involvement of Hsp60 in the coral immune response and implies its usefulness as a tool to evaluate physiological stress caused by coral diseases (Seveso et al. 2012).

In line with the above studies, the present work investigated the effect of BrB ciliates on the physiology of coral tissue during disease progression through analysis of the modulation of mitochondrial Hsp60. This was performed by measuring Hsp60 levels in coral polyps situated at 3 different distances away from the disease lesion in colonies of the staghorn coral A. muricata, which is one of the most analyzed widespread species affected by the $\mathrm{BrB}$ syndrome worldwide (Ulstrup et al. 2007, Bourne et al. 2008, Lobban et al. 2011, Sweet \& Bythell 2012, Nicolet et al. 2013).

\section{MATERIALS AND METHODS}

\section{Study area and sampling design}

In December 2013, after extensive surveys, a defined sampling area of $\sim 200 \mathrm{~m}^{2}$ located $\sim 80 \mathrm{~m}$ from the shore and composed of several coral patches was chosen in the lagoon of Magoodhoo Island $\left(3^{\circ} 04^{\prime} 42^{\prime \prime} \mathrm{N}, 72^{\circ} 57^{\prime} 50^{\prime \prime} \mathrm{E}\right)$, in the southeastern part of Faafu Atoll, Republic of Maldives (Fig. 1). This site was selected as it had been affected by BrB disease episodes in the past (Montano et al. 2012) and permitted easy and quick access suitable for rapid sampling activities. In addition, it extends along the same reef flat zone characterized by similar depths $(\sim 2-3 \mathrm{~m})$ and may thus be subjected to the same environmental conditions. To confirm this, 3 HOBO pendant data loggers (Onset, UA-002-64) were placed in different locations within the whole area a few days before sampling, and were maintained until the end of the sampling in order to measure sea temperature and light intensity. In parallel, seawater samples were collected for salinity measurements with a refractometer (Milwaukee Instruments). Colonies of the branching coral Acropora muricata of similar size and exhibiting symptoms of $\mathrm{BrB}$ disease were randomly selected, tagged and photographed (Canon G11 with Canon housing) by snorkelers. To ensure that only colonies displaying active disease were sampled, colonies were monitored every $2 \mathrm{~d}$ prior to the sampling activity and only those showing lesion progression were subsequently sampled and analyzed to study Hsp60 modulation. Furthermore, we selected colonies in which the BrB band was located at approximately the same distance from the tips of the coral branches. 


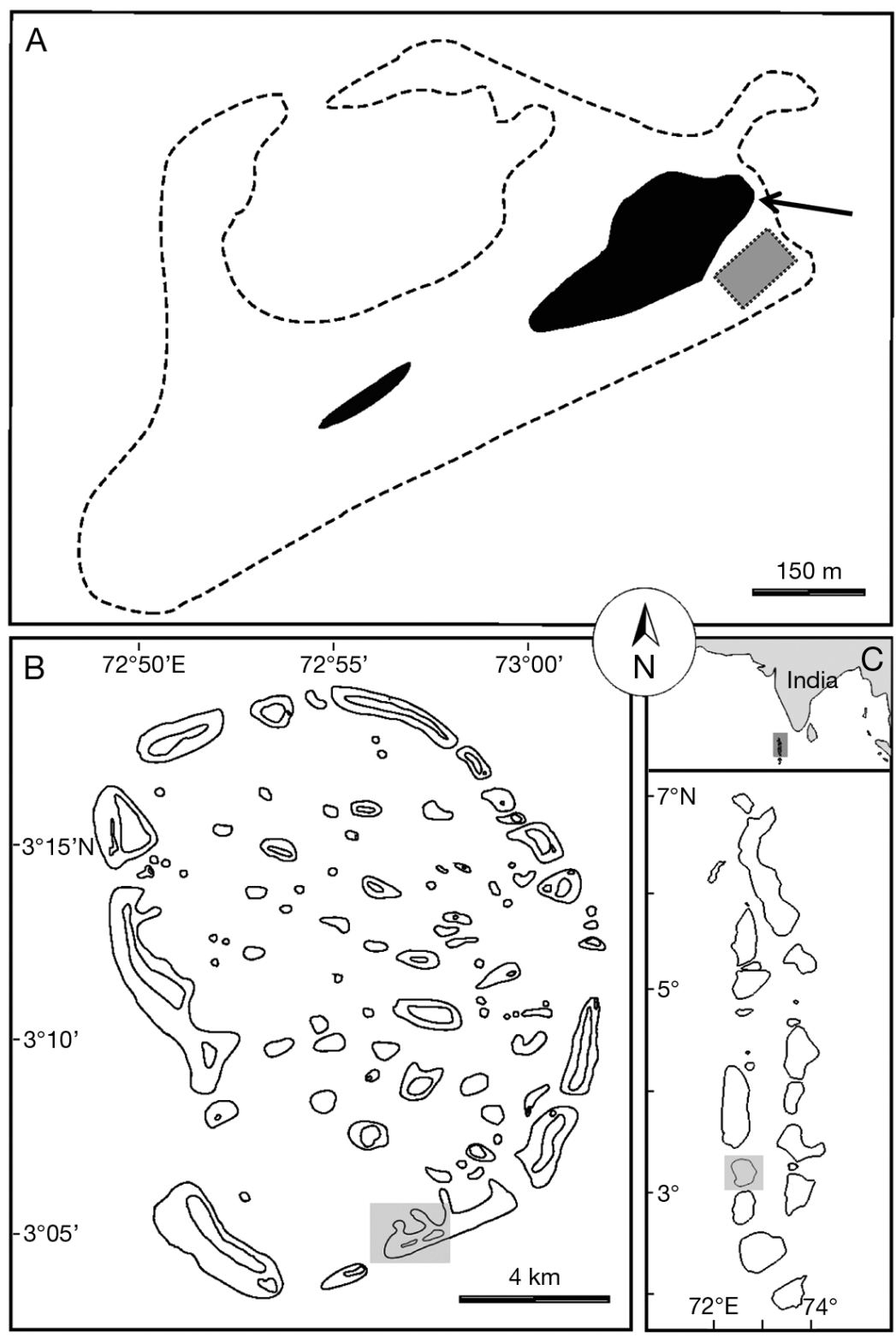

Fig. 1. Magoodhoo Island (A) located in the southeastern part of Faafu Atoll (B), Republic of Maldives (C). In A, black areas: the islands, black arrow: position of the MaRHE Centre on the island, dashed lines: the reef edges, grey rectangle: sampling site (area $\sim 250 \mathrm{~m}^{2}$, $\sim 80 \mathrm{~m}$ from the Magoodhoo lagoon shore) chosen for fast and easy access (see 'Materials and methods'). Distance between coral patches inside this sampling area vary from 5 to $15 \mathrm{~m}$. Within the area, 3 data

loggers were placed to record seawater temperature and light intensity

The coral fragments sampled at $\sim 1 \mathrm{~cm}$ from the site of infection just adjacent to the brown band, along the advancing front of the ciliate mass, were marked as distance 1 (D1). The coral fragments sampled approximately 5-10 cm away from the site of infection were marked as distance 2 (D2). Finally, the portions sampled far from the disease lesion ( 15-20 cm away) were marked as distance 3 (D3) (Fig. 2A). In some fragments, a thin white zone of exposed skeleton was observed between the ciliate band and the healthy tissue that may comprise bleached tissue and/or denuded skeleton (Willis et al. 2004, Lobban et al. 2011) (Fig. 2B). In these fragments, the collection of coral fragments was started from the first portions of living tissue situated just above these thin white bands. Coral samples were excised from colonies of $A$. muricata using a hollow-point stainless steel spike (8 $\mathrm{mm}$ diameter) by applying constant rotational pressure to minimize the size of coral sampled; this also minimized the amount of sampling stress and limited excessive damage to the colonies, thereby allowing rapid coral recovery following the sampling (Bromage et al. 2009). Each sample was collected with a new hollow-point spike to avoid contamination. Samples were then immediately frozen at $-80^{\circ} \mathrm{C}$ using an immersion cooler (FT902, JULABO, Labortechnick) in the MaRHE Centre laboratory at Maghodhoo Island, which is located a few meters away from the sampling area.

All coral samples were taken simultaneously at 09:00 $\mathrm{h}$ at the same shallow depth and during high tide (coral permanently submerged)

\section{Coral collection}

Among the selected colonies, 6 were randomly chosen and 3 intact and apparently healthy small coral fragments were collected from each of them. The fragments were obtained from the same coral branch at 3 different distances from the brown band, along the disease progression direction (Fig. 2A). to minimize seasonal and/or daily variations in water temperature, UV intensity and salinity (Chow et al. 2009, 2012, Seveso et al. 2013). Furthermore, in order to confirm that ciliate infection was associated with the disease in all the analyzed colonies, coral fragments corresponding to the brown bands were also collected together with the samples D1, D2 and D3. In these fragments, the infection caused 


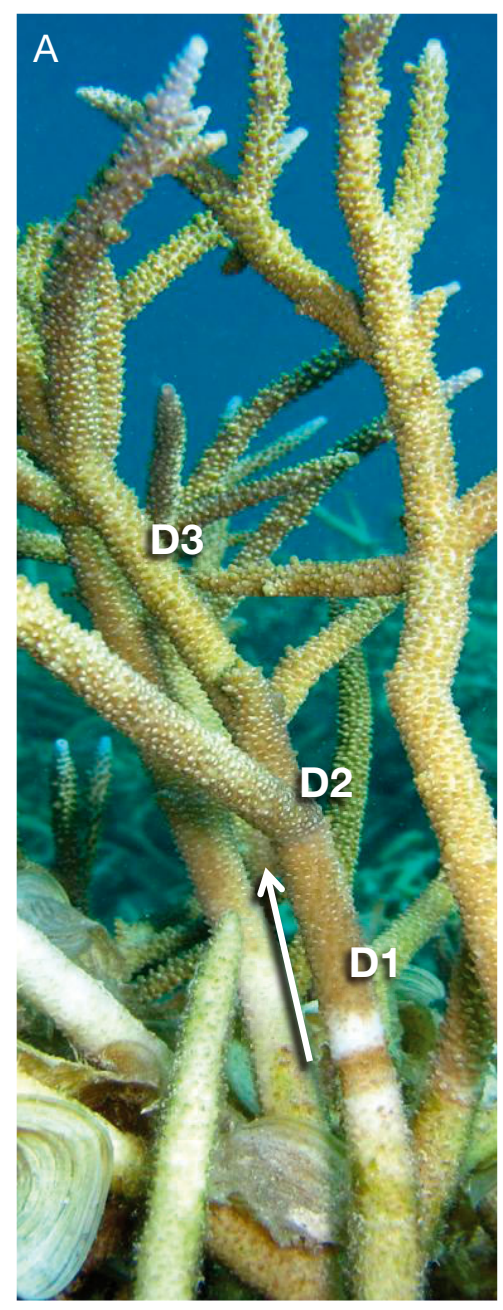

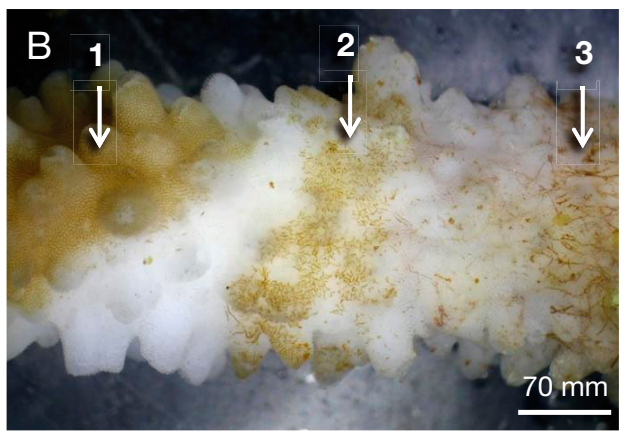
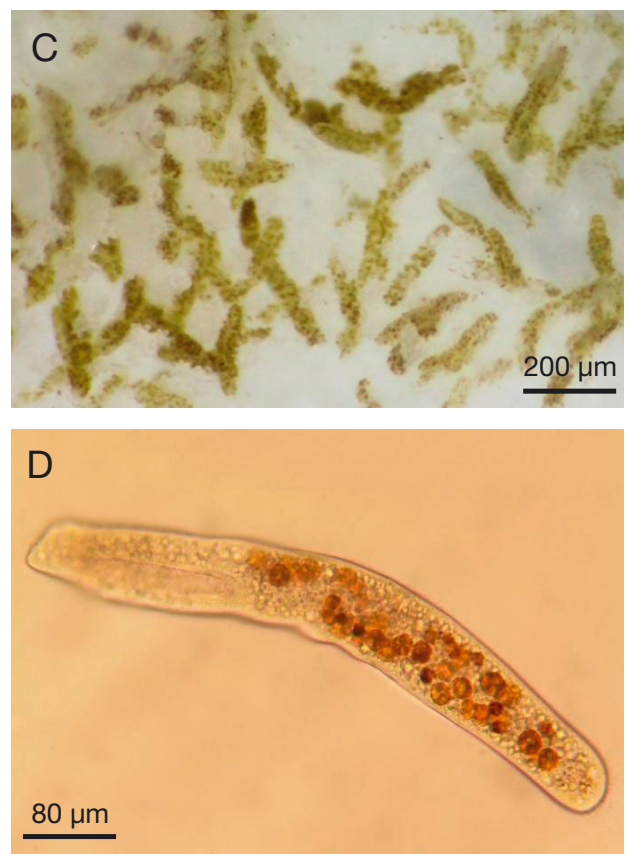

Fig. 2. (A) Colony of Acropora muricata affected by brown band (BrB) disease. White arrow: disease progression direction; D1, D2 and D3: sampling points along a coral fragment (just above the ciliate mass, at $5-10 \mathrm{~cm}$ and at $15-20 \mathrm{~cm}$ away from the site of infection, respectively). (B) Infected area on a branch showing the macroscopic signs of BrB disease including (1) healthy coral tissue in front of the advancing ciliate band, (2) the mass of swarming ciliates responsible for the infection, apparently wedged into the coral skeleton and (3) the exposed white coral skeleton (already covered by algae) following the ciliate infection. (C) Micrograph of the ciliate clustering that constitutes the band and is embedded in the coral skeleton after ingestion of coral tissue. Ciliates appear as brown flecks on the white coral. The ciliate population appeared uniform and was dominated by one morphologically distinct protozoan. (D) Micrograph (40× magnification) showing the morphology of the brown band ciliate. Note the intact intracellular zooxanthellae (Symbiodinium sp.) inside the ciliate by $\mathrm{BrB}$ ciliates was confirmed by microscopic analysis (Fig. 2B-D). Photomicrographs of the infected tissues containing ciliates were obtained using a stereomicroscope (Olympus SZ61) paired with a cold light source (Schott KL 300 LED), a camera (Olympus LC 20) and a microscope (Zeiss Axioskop, Carl Zeiss). To avoid contamination of the D1, D2 and D3 samples with other protozoans during the analysis of Hsps60, the total absence of protozoans was carefully verified by microscopic examination of each frozen sample prior to their homogenization. As control, 6 isolated and entirely healthy colonies of $A$. muricata were randomly selected within the same sampling area, considering only those located at least $10 \mathrm{~m}$ away from diseased colonies. For each colony, coral fragments were collected at 3 different distances (C1, C2 and C3) from the tip of the coral branch corresponding approximately to the same fixed distances of samples in the diseased branches.

\section{Western analysis}

The frozen coral fragments were pulverized using a mortar and a pestle and polyp proteins were extracted as previously described by Seveso et al. (2013, 2014), removing any Symbiodinium contamination from the extracts. All protein samples were frozen at $-20^{\circ} \mathrm{C}$ until used. Protein concentration was determined using the Bio-Rad protein assay kit (Bio-Rad Laboratories). Aliquots of proteins were separated by SDS-PAGE on $8 \%$ polyacrylamide gels (Vai et al. 1986) and duplicate gels were run in parallel. After electrophoresis, one gel was stained with Coomassie Brilliant Blue to visualize the total proteins and the other electroblotted onto nitrocellulose membrane for western blotting. Correct protein transfer was confirmed by Ponceau S Red (Sigma-Aldrich) staining of filters. For each blot, 75 ng of standard recombinant human Hsp60 (Enzo Life Sciences) was included as an internal control for signal differences 
across blots and also for quantification. Immunostaining was performed with anti-Hsp60 monoclonal antibody (IgG mouse clone LK-2, SPA-807, Enzo Life Sciences), anti- $\beta$-Actin monoclonal antibody (clone C4, MAB1501, Millipore) and secondary antibody anti-mouse IgG conjugated with horseradish peroxidase (Thermo Scientific) as previously reported (Seveso et al. 2013). Binding was visualized using Pierce ECL western blotting substrate followed by X-ray films.

Densitometric analysis was performed on a calibrated imaging densitometer (Bio-Rad GS-800) and the band intensities were quantified using the Image $\mathrm{J}$ free software (http://rsb.info. nih.gov/ij/). For each blot, the scanned intensity of the Hsp60 bands was normalized against the intensity of the $\beta$ Actin bands, which did not display a significant modulation at the different distances from the brown band, and were consequently used as internal loading control. To quantify the amount of Hsp60 expressed, the scanned intensity of the Hsp60 bands for each blot was normalized against the intensity of the Hsp60 protein standard. Data were expressed as means \pm SEMs. Data normality was verified using a ShapiroWilk test. One-way ANOVA followed by Tukey's HSD post hoc tests for pairwise comparison of means was performed for all the normalized Hsp60 intensity values obtained from the different groups of samples (C1,C2, C3 and D1, D2, D3).

\section{RESULTS AND DISCUSSION}

In all the Acropora muricata colonies affected by BrB disease, the microscopic analyses of the coral fragments collected at the level of the dark band revealed the presence of a dense mass of ciliates consuming the coral tissue and the total absence of living polyp tissue (Fig. 2B,C). As shown in Fig. 2D, the ciliates have an elongated, tube-like shape that is rounded at both posterior and apical ends, similar to other described ciliate taxa responsible for coral $\mathrm{BrB}$ disease (Bourne et al. 2008, Lobban et al. 2011, Sweet \& Bythell 2012). Despite the extensive literature that highlights the opportunistic nature of BrB ciliates in
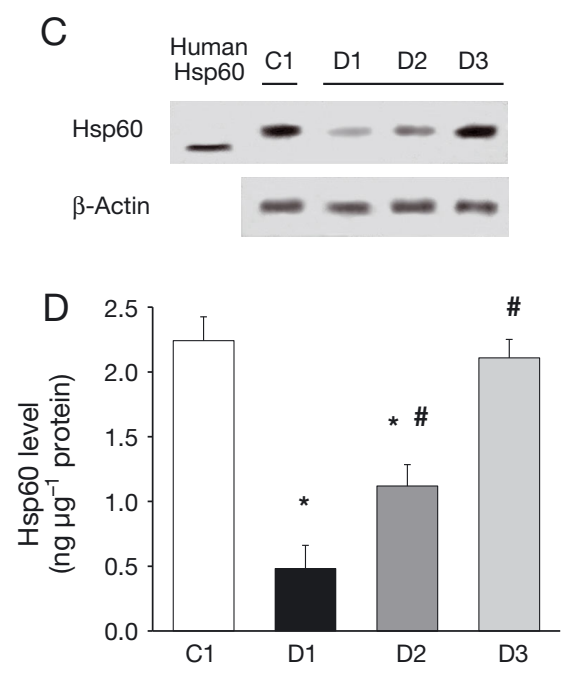

Fig. 3. (A) Hsp60 levels in healthy colonies of Acropora muricata. Samples of ranch (C1, C2 and C3) were subjected to Western blotting. Immunostaining performed with anti-Hsp60 and anti- $\beta$-Actin antibodies. Equal amounts recombinant human Hsp60 was included. A filter representing 6 experimental repeats $(n=6)$ is shown. (B) Hsp60 levels (mean \pm SEM) were determined by densitometric analysis (described in 'Materials and methods'). Signals of 6 BrB disease on Hsp60 modulation. Samples of coral fragments located at diferent distances from the brown band along the disease progren immunostaining as in A. Samples prepared from healthy colonies (C1) are also shown. A filter representing 6 experimental repeats $(n=6)$ is shown. D) Hsp60 levels (mean \pm SEM) were determined by densitometric analysis. * $\mathrm{p}<0.05$ compared to $\mathrm{C} 1, \# \mathrm{p}<0.05$ compared to D1 (1-way ANOVA followed by Tukey's HSD multiple pairwise comparisons)

rapidly invading corals through several vectors and their high rates of spreading, reproduction, virulence and tissue consumption (Ulstrup et al. 2007, Nugues \& Bak 2009, Katz et al. 2014, Randall et al. 2015), little is currently known about the mechanisms employed by corals to fight and resist ciliate infection. For this reason the expression of Hsp60, which represents a useful molecular biomarker for detecting early signs of change in a coral's physiological state caused by both abiotic and biotic stresses (Brown et al. 2002, Downs et al. 2005, Chow et al. 2012, Seveso et al. 2013, 2014), was analyzed in coral affected by the $\mathrm{BrB}$ disease at different distances along the advancing front of the infection.

In all the healthy colonies of $A$. muricata chosen as control, no significant difference in Hsp60 levels was detected among coral fragments collected at different distances from the tip of the coral branch (Fig. 3A). Based on densitometric analysis (Fig. 3B), a similar basal level of Hsp60 was found (2.24 \pm 0.18 , 
Table 1. Tukey's HSD multiple pairwise comparisons of means for all the normalized Hsp60 intensity values obtained from the different groups of samples $(\mathrm{C} 1, \mathrm{C} 2, \mathrm{C} 3$ and D1, D2, D3). N = 6 for each group. Statistically significant differences $(p<0.05)$ are indicated in bold

\begin{tabular}{|ccccccc|}
\hline & C1 & C2 & C3 & D1 & D2 & D3 \\
\hline C1 & - & 0.75 & 0.887 & $\mathbf{0 . 0 0 1}$ & $\mathbf{0 . 0 0 6}$ & 0.832 \\
C2 & 0.75 & - & 0.999 & $\mathbf{0 . 0 0 4}$ & $\mathbf{0 . 0 0 8}$ & 0.999 \\
C3 & 0.887 & 0.999 & - & $\mathbf{0 . 0 0 3}$ & $\mathbf{0 . 0 0 7}$ & 0.999 \\
D1 & $\mathbf{0 . 0 0 1}$ & $\mathbf{0 . 0 0 4}$ & $\mathbf{0 . 0 0 3}$ & - & $\mathbf{0 . 0 1 6}$ & $\mathbf{0 . 0 0 4}$ \\
D2 & $\mathbf{0 . 0 0 6}$ & $\mathbf{0 . 0 0 8}$ & $\mathbf{0 . 0 0 7}$ & $\mathbf{0 . 0 1 6}$ & - & $\mathbf{0 . 0 0 9}$ \\
D3 & 0.832 & 0.999 & 0.999 & $\mathbf{0 . 0 0 4}$ & $\mathbf{0 . 0 0 9}$ & - \\
\hline
\end{tabular}

$2.09 \pm 0.23$ and $2.12 \pm 0.23 \mathrm{ng} \mathrm{Hsp} 60 \mathrm{\mu g}^{-1}$ proteins in coral fragments $\mathrm{C} 1, \mathrm{C} 2$ and $\mathrm{C} 3$, respectively (ANOVA, Tukey's HSD post hoc tests for pairwise comparison of means; $\mathrm{p} \geq 0.05$ comparing $\mathrm{C} 1, \mathrm{C} 2$ and C3; Table 1). This also confirms the important role of this chaperonin even under normal physiological conditions (Choresh et al. 2001, Chow et al. 2009, Seveso et al. 2014). Consequently, only a representative control sample (C1) is shown in Fig. 3C. In contrast, a modulation of Hsp60 was observed in A. muricata infected by $\mathrm{BrB}$ disease, with different Hsp60 levels being found in the different parts of the same colony, suggesting that the distance from the diseased polyps can affect the Hsp60 trend (Fig. 3C). In fact, a strong down-regulation of Hsp60 expression was detected near the infected portions of the coral, with protein levels progressively increasing with distance from the dark band and returning to levels comparable to that found in the control only at the farthest distance from the band (D3). The densitometric analysis confirmed that Hsp60 levels approached values close to zero $(0.48 \pm 0.18 \mathrm{ng}$ Hsp60

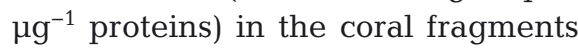
sampled just above the dark band (D1) on the interface of ciliate progression (Fig. 3D), resulting in significantly lower values than those detected in the control (ANOVA, Tukey's HSD post hoc tests for pairwise comparison of means; $p<0.05$ when compared to $\mathrm{C} 1$; Table 1). At an intermediate distance (D2), the Hsp60 signal was slightly but significantly increased compared to D1 (1.12 \pm $0.16 \mathrm{ng}$ Hsp60 $\mathrm{\mu g}^{-1}$ proteins). However, the protein level was still markedly lower than that of the healthy colonies $(\mathrm{p}<0.05$ when compared to $\mathrm{C} 1$; Table 1). Finally, in coral fragments sampled farthest from the dark band (D3), the Hsp60 level was almost twice compared to that in D2 $(2.11 \pm 0.14 \mathrm{ng}$ Hsp60 $\mu^{-1}$ proteins) and reverted to values close to those in the control samples ( $\mathrm{p} \geq 0.05$ when compared to $\mathrm{C} 1$, $\mathrm{p}<0.05$ when compared to D1) (Fig. 3C,D, Table 1). In order to highlight the presence of the infection as the sole cause of the Hsp60 trend in the A. muricata colonies, it should be noted that all the coral tissue samples displayed normal tissue pigmentation, did not show morphological differences, were free of necrosis and were undamaged structurally. Furthermore, no significant changes in temperature and light intensity were observed within different locations of the sampling area during the sampling time and among different days (Table 2). Seawater temperatures were consistent with the normal mean seasonal trend $(29.28 \pm 0.26)$ recorded during the northeast monsoon season from December to April. In addition, no anomalies in the salinity values $(\sim 35.5 \%$ o) were detected.

The mitochondrial chaperonin Hsp60 is essential in mitochondrial biogenesis and in the synthesis and transport of essential proteins from the cytoplasm into the mitochondrial matrix, playing a central role in the folding of newly imported and stress-denatured proteins in the mitochondria (Hood et al. 2003). Generally, the up-regulation of the Hsp60 level implies a general shift in the protein chaperoning and degradation within the mitochondria, accompanied by

Table 2. Sea temperature $\left({ }^{\circ} \mathrm{C}\right.$ ) and light intensity (lux) recorded by the 3 data loggers (DL1, DL2, DL3) placed in different locations within the sampling area. Values measured during 5 representative days randomly selected during the sampling period (December 2013) are reported. The means $( \pm \mathrm{SD})$ of both parameters recorded by the different data loggers in the different days are also shown

\begin{tabular}{|c|c|c|c|c|}
\hline Day & DL1 & DL2 & DL3 & Mean $( \pm \mathrm{SD})$ \\
\hline \multicolumn{5}{|c|}{ Temperature $\left({ }^{\circ} \mathbf{C}\right)$} \\
\hline Day 1 & 29.3 & 29.14 & 29.23 & $29.22( \pm 0.09)$ \\
\hline Day 2 & 29.5 & 29.32 & 29.51 & $29.44( \pm 0.11)$ \\
\hline Day 3 & 29.34 & 29.18 & 29.26 & $29.26( \pm 0.09)$ \\
\hline Day 4 & 29.25 & 29.49 & 29.32 & $29.35( \pm 0.13)$ \\
\hline Day 5 & 29.31 & 29.37 & 29.15 & $29.27( \pm 0.11)$ \\
\hline Mean $( \pm \mathrm{SD})$ & $29.34( \pm 0.10)$ & $29.3( \pm 0.14)$ & $29.29( \pm 0.14)$ & \\
\hline \multicolumn{5}{|c|}{ Light intensity (lux) } \\
\hline Day 1 & 29467 & 27101 & 25135 & $27234( \pm 2169)$ \\
\hline Day 2 & 29654 & 27346 & 30457 & $29152( \pm 1615)$ \\
\hline Day 3 & 31357 & 28679 & 24146 & $28060( \pm 3645)$ \\
\hline Day 4 & 28368 & 30114 & 25513 & $27997( \pm 2322)$ \\
\hline Day 5 & 25345 & 27674 & 29653 & $27557( \pm 2156)$ \\
\hline Mean $( \pm \mathrm{SD})$ & $28838( \pm 2226)$ & $28182( \pm 1235)$ & $26980( \pm 2864)$ & \\
\hline
\end{tabular}


changes in the equilibria of mitochondrial-associated metabolic pathways (Papp et al. 2003). In addition, this Hsp is also involved in the immune response, particularly interacting with the Toll-like receptor (TLR) signaling pathway (Pockley et al. 2008, Quintana \& Cohen 2011). In corals, many immune mechanisms for resisting infections and maintaining tissue integrity have been described, including TLRs, the melanin-synthesis pathway, a component of the prophenoloxidase pathway and antimicrobial and enzymatic activities (Geffen \& Rosenberg 2005, Mydlarz \& Harvell 2007, Palmer et al. 2008, 2011, 2012, Dunn 2009, Mydlarz et al. 2010, Palmer \& Traylor-Knowles 2012, Libro et al. 2013); however, few reports have examined the involvement of a Hsp in coral immune response to any coral disease (Seveso et al. 2012, Brown et al. 2013). In this context, transcriptional upregulation of the $h s p 70$ gene in the coral A. millepora infected by Vibrio coralliilyticus has been proposed to be an element of the defense response of the coral, possibly by activating other components of the coral effector immune systems, such as the prophenoloxidase cascade (Brown et al. 2013). Similarly, Baruah et al. (2011) presented evidence that Hsp70 up-regulation in the shrimp Artemia sp. increased resistance to pathogens by priming and enhancing the expression of the prophenoloxidase system.

Interestingly, our results showed that Hsp60 expression was higher in the coral portions farther from the disease front that can potentially be infected than in those closer to the infection. This modulation of the Hsp60 contrasts with that in the same coral species infected by the ciliate Halofolliculina corallasia that causes SEB disease in the same geographic area (Seveso et al. 2012); a significant increase in Hsp60 compared to the healthy control was observed in colonies near the advancing front of the ciliate mass. The extremely low level of Hsp60 observed in front line colonies affected by BrB could indicate that the defense mechanisms were probably already overly stressed and were unable to counteract the strong cellular stress produced by the ciliates. Consequently, the physiological status and health of these coral polyps could probably be already compromised and 'lost' by the organism. Thus, even in neighboring cells that were not yet directly infected, the ciliate presence could have caused cellular damage. The BrB ciliates have been observed to migrate along the length of branching corals from base to tip at a rate much faster than SEB ciliates do. While SEB progression rate in $A$. muricata has been estimated to be at a maximum of 1 to $2 \mathrm{~mm} \mathrm{~d}^{-1}$ (Antonius \& Lipscomb 2001, Page \& Willis 2008), the mean rate of BrB pro- gression on diseased branches of $A$. muricata in the field varies from 5 to $20 \mathrm{~mm} \mathrm{~d}^{-1}$ (Ulstrup et al. 2007, Lobban et al. 2011, Nicolet et al. 2013, Katz et al. 2014, Randall et al. 2015). We speculate that this rapid migration of the $\mathrm{BrB}$ ciliate would not give the coral defense mechanism the time necessary to react in an attempt to block and confine the infection.

Alternatively, since the BrB ciliates are only feeding on coral tissue and may not produce harmful secretions that could inhibit Hsp expression, the Hsp60 down-regulation observed could be explained by referring to a study aimed at establishing the microbial diversity (bacteria and ciliates) associated with the BrB disease (Sweet \& Bythell 2012). In this study, the authors suggested that bacteria such as Arcobacter sp. and Aeromonas sp., could be the primary disease causing agents in corals subjected to $\mathrm{BrB}_{i}$ by invading healthy tissues and impairing physiological functions, bacteria allow ciliates to subsequently invade and consume the coral tissues (Sweet \& Bythell 2012). In this context, one can hypothesize that the decrease in Hsp60 could be linked to toxic substances secreted by these pathogenic bacteria.

In conclusion, the present study provides new insights into the physiology of scleractinian corals subjected to epizootic disease. The results further support the notion that Hsp60 expression may constitute a useful tool for checking specific variations in coral physiological and cellular parameters, which cannot be detected simultaneously at the morphological level. Furthermore, the present data also suggest that different pathogens could trigger differences in Hsp modulation (cf. Seveso et al. 2012). Since ciliate feeding behavior and their role in coral tissue mortality remain unclear (Yarden et al. 2007), further investigation of other coral diseases and other molecular biomarkers is needed in order to elucidate major ecological and molecular aspects of pathogen-host relationships.

Acknowledgements. This work was partly conducted at the Marine Research and High Education Center (MaRHE) of the University of Milano-Bicocca in Magoodhoo Island (Faafu, Maldives). We thank all the MaRHE Center staff for the logistical support provided. We also thank Neil Campbell for English editing, Davide Maggioni and Andrea Stefano De Simone for assistance during the sampling activities, and especially Giovanni Strona for statistical analyses.

\section{LITERATURE CITED}

Antonius AA, Lipscomb D (2001) First protozoan coral-killer identified in the Indo-Pacific. Atoll Res Bull 481:1-21

Baruah K, Ranjan J, Sorgeloos P, MacRae TH, Bossier P (2011) Priming the prophenoloxidase system of Artemia 
franciscana by heat shock proteins protects against Vibrio campbellii challenge. Fish Shellfish Immunol 31: 134-141

Bourne DG, Boyett HV, Henderson ME, Muirhead A, Willis BL (2008) Identification of a ciliate (Oligohymenophorea: Scuticociliata) associated with brown band disease on corals of the Great Barrier Reef. Appl Environ Microbiol 74:883-888

> Bromage E, Carpenter L, Kaattari S, Patterson M (2009) Quantification of coral heat shock proteins from individual coral polyps. Mar Ecol Prog Ser 376:123-132

Brown BE, Downs CA, Dunne RP, Gibb SW (2002) Exploring the basis of thermotolerance in the reef coral Goniastrea aspera. Mar Ecol Prog Ser 242:119-129

Brown T, Bourne D, Rodriguez-Lanetty M (2013) Transcriptional activation of $\mathrm{c} 3$ and hsp70 as part of the immune response of Acropora millepora to bacterial challenges. PLoS ONE 8:e67246

Choresh O, Ron E, Loya Y (2001) The 60-kDa heat shock protein (HSP60) of the sea anemone Anemonia viridis: a potential early warning system for environmental changes. Mar Biotechnol (NY) 3:501-508

> Chow AM, Ferriere-Pagès C, Khalouei S, Reynaud S, Brown IR (2009) Increased light intensity induces heat shock protein Hsp60 in coral species. Cell Stress Chaperones 14:469-476

> Chow AM, Beraud E, Tang DWF, Ferrier-Pagès C, Brown IR (2012) Hsp60 protein pattern in coral is altered by environmental changes in light and temperature. Comp Biochem Physiol A Mol Integr Physiol 161:349-353

> Cróquer A, Bastidas C, Lipscomb D (2006) Folliculinid ciliates: a new threat to Caribbean corals? Dis Aquat Org 69:75-78

Downs CA, Fauth JE, Robinson CE, Curry R and others (2005) Cellular diagnostic and coral health: declining coral health in the Florida Keys. Mar Pollut Bull 51: 558-569

Dunn S (2009) Immunorecognition and immunoreceptors in the Cnidaria. Invert Surviv J 6:7-14

> Geffen Y, Rosenberg E (2005) Stress-induced rapid release of antibacterials by scleractinian corals. Mar Biol 146: 931-935

> Hartl FU, Bracher A, Hayer-Hartl M (2011) Molecular chaperones in protein folding and proteostasis. Nature 475 : 324-332

> Hood DA, Adhihetty PJ, Colavecchia M, Gordon JW and others (2003) Mitochondrial biogenesis and the role of the protein import pathway. Med Sci Sports Exerc 35: 86-94

Katz SM, Pollock FJ, Bourne DG, Willis BL (2014) Crown-ofthorns starfish predation and physical injuries promote brown band disease on corals. Coral Reefs 33:705-716

> Lamb JB, Willis BL (2011) Using coral disease prevalence to assess the effects of concentrating tourism activities on offshore reefs in a tropical marine park. Conserv Biol 25:1044-1052

Lanneau D, Brunet M, Frisan E, Solary E, Fontenay M, Garrido C (2008) Heat shock proteins: essential proteins for apoptosis regulation. J Cell Mol Med 12:743-761

> Libro S, Kaluziak ST, Vollmer SV (2013) Rna-seq profiles of immune related genes in the staghorn coral Acropora cervicornis infected with white band disease. PLoS ONE 8:e81821

Lobban CS, Raymundo LM, Montagnes DJS (2011) Propostoma guamense n. sp., a philasterine scuticociliate associated with brown-band disease of corals. J Eukaryot Microbiol 58:103-113

- Mayer MP (2010) Gymnastics of molecular chaperones. Mol Cell 39:321-331

> Montano S, Strona G, Seveso D, Galli P (2012) First report of coral diseases in the Republic of Maldives. Dis Aquat Org 101:159-165

- Montano S, Strona G, Seveso D, Galli P (2013) Prevalence, host range, and spatial distribution of black band disease in the Maldivian Archipelago. Dis Aquat Org 105:65-74

Montano S, Strona G, Seveso D, Maggioni D, Galli P (2014) Slow progression of black band disease in Goniopora $\mathrm{cf}$. columna colonies may promote its persistence in a coral community. Mar Biodiv doi:10.1007/s12526-014-0273-9

> Mydlarz LD, Harvell CD (2007) Peroxidase activity and inducibility in the sea fan coral exposed to a fungal pathogen. Comp Biochem Physiol A Mol Integr Physiol 146:54-62

Mydlarz LD, McGinty ES, Harvell CD (2010) What are the physiological and immunological responses of coral to climate warming and disease? J Exp Biol 213:934-945

- Nicolet KJ, Hoogenboom MO, Gardiner NM, Pratchett MS, Willis BL (2013) The corallivorous invertebrate Drupella aids in transmission of brown band disease on the Great Barrier Reef. Coral Reefs 32:585-595

Nugues MM, Bak RPM (2009) Brown-band syndrome on feeding scars of the crown-of-thorn starfish Acanthaster planci. Coral Reefs 28:507-510

Page CA, Willis BL (2008) Epidemiology of skeletal eroding band on the Great Barrier Reef and the role of injury in the initiation of this widespread coral disease. Coral Reefs 27:257-272

> Palmer CV, Traylor-Knowles N (2012) Towards an integrated network of coral immune mechanisms. Proc R Soc B 279:4106-4114

> Palmer CV, Mydlarz LD, Willis BL (2008) Evidence of an inflammatory-like response in non-normally pigmented tissues of two scleractinian corals. Proc R Soc B 275: 2687-2693

Palmer CV, McGinty ES, Cummings DJ, Smith SM, Bartels E, Mydlarz LD (2011) Patterns of coral ecological immunology: variation in the responses of Caribbean corals to elevated temperature and a pathogen elicitor. J Exp Biol 214:4240-4249

> Palmer CV, Bythell JC, Willis BL (2012) Enzyme activity demonstrates multiple pathways of innate immunity in Indo-Pacific corals. Proc R Soc B 279:3879-3887

> Papp E, Nardai G, Soti C, Csermely P (2003) Molecular chaperones, stress proteins and redox homeostasis. Biofactors 17:249-257

Pockley AG, Muthana M, Calderwood SK (2008) The dual immunoregulatory roles of stress proteins. Trends Biochem Sci 33:71-79

Quintana FJ, Cohen IR (2011) The Hsp60 immune system network. Trends Immunol 32:89-95

> Randall CJ, Jordán-Garza AG, van Woesik R (2015) Ciliates associated with signs of disease on two Caribbean corals. Coral Reefs 34:243-247

Raymundo LJ, Halford AR, Maypa AP, Kerr AM (2009) Functionally diverse reef-fish communities ameliorate coral diseases. Proc Natl Acad Sci USA 106: $17067-17070$

> Ross C (2014) Nitric oxide and heat shock protein 90 coregulate temperature-induced bleaching in the soft coral Eunicea fusca. Coral Reefs 33:513-522 
Rossi S, Snyder MJ, Gili JM (2006) Protein, carbohydrate, lipid concentrations and HSP70-HSP90 (stress protein) expression over an annual cycle: useful tools to detect feeding constraints in a benthic suspension feeder. Helgol Mar Res 60:7-17

Seveso D, Montano S, Strona G, Orlandi I, Vai M, Galli P (2012) Up-regulation of Hsp60 in response to skeleton eroding band disease but not by algal overgrowth in the scleractinian coral Acropora muricata. Mar Environ Res 78:34-39

Seveso D, Montano S, Strona G, Orlandi I, Galli P, Vai M (2013) Exploring the effect of salinity changes on the levels of Hsp60 in the tropical coral Seriatopora caliendrum. Mar Environ Res 90:96-103

Seveso D, Montano S, Strona G, Orlandi I, Galli P, Vai M (2014) The susceptibility of corals to thermal stress by analyzing Hsp60 expression. Mar Environ Res 99:69-75

Sorensen JG, Kristensen TN, Loeschcke V (2003) The evolutionary and ecological role of heat shock proteins. Ecol Lett 6:1025-1037

Sutherland KP, Porter JW, Torres C (2004) Disease and immunity in Caribbean and Indo-Pacific zooxanthellate corals. Mar Ecol Prog Ser 266:273-302

Sweet M, Bythell J (2012) Ciliate and bacterial communities associated with White Syndrome and Brown Band Disease in reef-building corals. Environ Microbiol 14: 2184-2199

Sweet M, Craggs J, Robson J, Bythell J (2013) Assessment of the microbial communities associated with white syndrome and brown jelly syndrome in aquarium corals. J Zoo Aquar Res 1:20-27

Tsan MF, Gao B (2009) Heat shock proteins and immune system. J Leukoc Biol 85:905-910

Ulstrup KE, Kühl M, Bourne DG (2007) Zooxanthellae harvested by ciliates associated with brown band syndrome of corals remain photosynthetically competent. Appl Environ Microbiol 73:1968-1975

> Vai M, Popolo L, Alberghina L (1986) Immunological crossreactivity of fungal and yeast plasma membrane $\mathrm{H}^{+}$ATPase. FEBS Lett 206:135-141

Weil E, Smith G, Gil-Agudelo DL (2006) Status and progress in coral reef disease research. Dis Aquat Org 69:1-7

Weil E, Irikawa A, Casareto B, Suzuki Y (2012) Extended geographic distribution of several Indo-Pacific coral reef diseases. Dis Aquat Org 98:163-170

Willis BL, Page CA, Dindsdale EA (2004) Coral disease in the Great Barrier Reef. In: Rosenberg E, Loya Y (eds) Coral health and disease. Springer-Verlag, Berlin, p 9-104

Yarden O, Ainsworth TD, Roff G, Leggat W, Fine M, HoeghGuldberg $O$ (2007) Increased prevalence of ubiquitous ascomycetes in an acropoid coral (Acropora formosa) exhibiting symptoms of brown band syndrome and skeletal eroding band disease. Appl Environ Microbiol 73:2755-2757

Submitted: November 10, 2014; Accepted: March 30, 2015 Proofs received from author(s): June 5, 2015
Editorial responsibility: Garriet Smith, Aiken, South Carolina, USA 